\title{
A Comparative Study of Indonesian Estimated Rice Production and Consumption
}

\section{Tri Anggraeni}

Pusat Penelitian dan Pengabdian kepada Masyarakat, Sekolah Tinggi Multi Media "MMTC" Yogyakarta, Indonesia. E-mail: tri.anggraeni@mmtc.ac.id

\section{ARTICLE INFO}

Keywords: comparative study, import policy, rice import, production and consumption

Kata kunci: studi perbandingan, kebijakan impor, impor beras, produksi dan konsumsi

\section{How to cite:}

Anggraeni, T. (2020). A Comparative Study of Indonesian Estimated Rice Production and Consumption. JAKPP (Jurnal

Analisis Kebijakan dan Pelayanan Publik, 6(2), 101-112.

\section{ABSTRACT}

The permit of two million tons of rice import in 2018 has tickled Indonesia's ability to fulfill its own rice needs. Farmers' anxiety that rice import can affect rice prices proved by its declining. The distribution of imported rice indeed has not been optimal. People say that imports are carried out without proper planning. This study aims to estimate the rice production and consumption data of Indonesia in 2014 to 2019, compare those data, and conclude whether Indonesia needs to import the rice at those years based on the comparison result. Estimating rice production and consumption were carried out using secondary data consisted of paddy production data, per capita rice consumption data, and population projection data which obtained from the website of the Central Statistics Agency (BPS) and/or the Ministry of Agriculture. Based on the comparison result between rice production and consumption data from 2014 to 2019, it can be concluded that from 7 islands in Indonesia, only 2 islands have the estimated rice consumption which always more than the estimated production, namely Maluku and Papua. The total estimated rice consumption in Indonesia is always lower than the estimated production. A rice surplus on a nearby island, Sulawesi, should be able to cover shortages in Maluku and Papua. If the estimated rice consumption in these three islands is totaled, the amount is always smaller than the estimated rice production in these three islands. This is because the production of rice on the island of Sulawesi is very large. The estimated total consumption of rice in 2019 is only $60 \%$ of production.

\footnotetext{
Abstrak

Impor beras sekitar dua juta ton dari Vietnam pada tahun 2018 menggelitik kemampuan Indonesia dalam memenuhi kebutuhan beras sendiri. Kekhawatiran petani bahwa impor beras dapat mempengaruhi harga beras terbukti dengan telah turunnya harga tersebut. Distribusi beras yang telah diimpor pun ternyata belum optimal. Banyak pihak mengatakan bahwa impor dilakukan tanpa ada perencanaan yang baik. Penelitian ini bertujuan untuk memperkirakan produksi dan konsumsi beras Indonesia tahun 2014 sampai 2019, membandingkannya, dan menyimpulkan perlu/tidaknya impor beras dari hasil perbandingan tersebut. Perkiraan produksi dan konsumsi beras dilakukan menggunakan data-data sekunder yang terdiri atas data produksi padi, data konsumsi beras per kapita, dan data proyeksi penduduk yang diperoleh dari situs web Badan Pusat Statistik (BPS) dan/atau Kementerian
} 


\begin{abstract}
Pertanian. Dari hasil perbandingan antara data produksi dan konsumsi beras pada tahun 2014 sampai 2019 dapat disimpulkan bahwa dari 7 pulau di Indonesia, hanya 2 pulau yang perkiraan konsumsi berasnya selalu lebih dari perkiraan produksinya, yaitu Pulau Maluku dan Papua. Total perkiraan konsumsi beras di Indonesia selalu masih lebih rendah daripada perkiraan produksi. Surplus beras di pulau terdekat yaitu Sulawesi seharusnya dapat menutupi kekurangan di Maluku dan Papua. Jika perkiraan konsumsi beras di ketiga pulau ini ditotal, jumlahnya selalu lebih kecil daripada perkiraan produksi beras di ketiga pulau ini. Hal ini dikarenakan produksi beras di Pulau Sulawesi sangat besar. Total perkiraan konsumsi beras di tahun 2019 hanya $60 \%$ dari produksinya.
\end{abstract}

\title{
Introduction
}

The permit of two million tons of rice import in 2018 has tickled Indonesia's ability to fulfill its own rice needs (Maulida, 2018). The Ministry of Trade's Director General of Foreign Trade stated that Indonesia could import rice from Thailand, Cambodia, Vietnam, Myanmar, Pakistan, and India. The issue of imports can make farmers anxious (Nainggolan, 2018). The Chairperson of the Indonesian Farmers Association considers the rice import discourse can cause the price of grain to drop. The issue can also lead to the emergence of rice cartel practices, namely large traders who are not necessarily rice traders who commit fraud by stockpiling existing stocks so that stock in the market runs out (Herdahita \& Aini, 2015). Chairperson of the Indonesian Market Traders Association (Ikappi) stated that this condition could occur due to weak data collection of rice production and surplus area. On the other hand, the distribution of imported rice has not been optimal. Several regions need but have not obtained any of it (Ian, 2015). There is an accusation that rice imports are evidence of the failure of Bulog in absorbing the rice production (Fitri \& Rachman, 2015).

On March 2020, the expert staff of Coordinating Ministry for Economic Affairs Raden Edi Prio Pambudi said that the government would re-open rice imports to ensure supply availability and maintain price stability ahead of religious holidays (Thomas, 2020). According to data from the Central Statistics Agency (BPS), Indonesia's rice production in 2019 was in the range of 31.31 million tons, 2.63 million tons lower or equivalent to 7.75 percent from 2018 which touched 33.94 million tons. Meanwhile, the need for rice was only 29.6 million tons per year, so there was a surplus of 4.37 million tons in 2018 and 1.53 million tons in 2019.

Meanwhile, we can get some data about the total of a country's land area, agricultural land area, and the percentage from the World Bank as shown in Table 1. Data displayed is 2016 because the last available agricultural area data is in that year. It can be seen that although the land ares of Indonesia is wider than India, Pakistan, Thailand, and Vietnam, the percentage of agricultural area in is indeed higher than Indonesia. 
Tabel 1. The Total of Country's Land Area, Agricultural Land Area, and the Percentage of Indonesia and the Rice Import Country Origin in 2016

\begin{tabular}{cccc}
\hline Country & Land area $^{1)}$ & Agricultural land area ${ }^{2)}$ & $\begin{array}{c}\text { The persentage of } \\
\text { Agricultural land area }\end{array}$ \\
\hline Indonesia & 1.811 .570 & 570.000 & 31,5 \\
India & 2.973 .190 & 1.797 .210 & 60,4 \\
Kamboja & 176.520 & 54.550 & 30,9 \\
Myanmar & 653.080 & 127.600 & 19,5 \\
Pakistan & 770.880 & 368.440 & 47,8 \\
Thailand & 510.890 & 221.100 & 43.3 \\
Vietnam & 310.070 & 121.780 & 39,3 \\
\hline
\end{tabular}

Source: 1) World Bank (2019a), 2) World Bank (2019b), 3) World Bank (2019c)

Chairperson of the Indonesian House of Representatives Bambang Soesatyo commented on the Ministry of Commerce's rice import decision (Pitoko, 2018). There is no similarity between the data from three government institutions (Ministry of Agriculture, Ministry of Trade, and State Logistics Agency or Bulog). In addition, there is no single agency that has published data about the estimation of national rice production and consumption, so it seems likely that rice is in short supply and requires imports. On the website of the Central Statistics Agency (BPS) there is important data on rice from 2000 to 2018 (BPS, 2019). The graph of these numbers is shown in Figure 1. The number of imports was the highest in 2011, then decreased in 2012 and 2013. Unfortunately, the number crept up in 2014 to 2016. Even though it had decreased in 2017, this number increased drastically again in 2018.

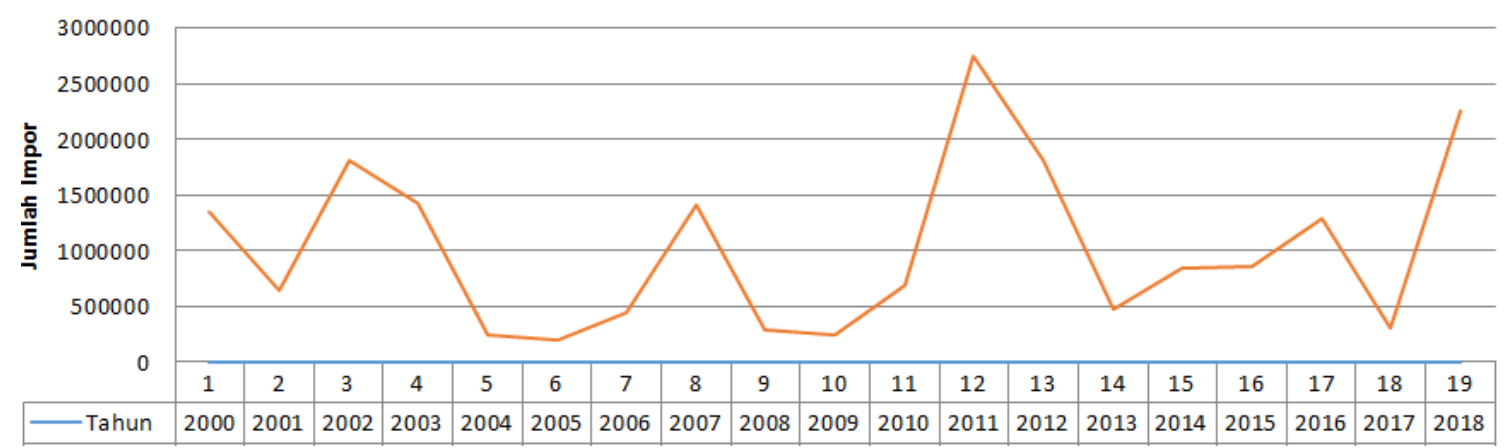

Gambar 1. Impor beras dari tahun 2000-2018

Source: BPS (2019)

The President stated that the import policy aims to maintain the availability of rice reserves if there are natural disasters and crop failure and to stabilize domestic rice prices (Erdianto \& Belarminus, 2019). But in December 2019, Bulog discarded 20 thousand tons of its rice stock (Yuliawati \& Alika, 2019). Professor of 
the Faculty of Agriculture, IPB University - Dwi Andreas Santosa - assessed that the chaotic rice supply data made the import policy wrong.

There are several studies which comparing rice production and consumption data, but all of them are conducted only for total data of Indonesia. The latest year that shows this data is 2013 (Abidin, 2015). There are no publications that inform this comparison for the last 6 years (2014 - 2019), even though this is very important to evaluate the adequacy of Indonesia's rice availability. This condition prompted a comparative study about rice production and consumption estimation to be carried out.

\section{Literature Review}

There were several studies comparing rice production and consumption data. Abidin (2015) calculates rice production from paddy production multiplied by the conversion rate of rice production. The need for rice is calculated from the total population multiplied by per capita consumption. From the comparison between those rice production and necessity, Abidin stated that from 2009 to 2013 Indonesia experienced a rice surplus. Santosa et al (2011) and Rungkat et al (2014) also used this method of calculating rice demand to calculate rice consumption.

\section{Method}

This study used descriptive qualitative analysis because it describes the object under study. The data was in the form of secondary data collected from the website of the Ministry of Agriculture and the Central Bureau of Statistics (BPS). These data consisted of data on Indonesian paddy production from 2014 to 2019 and data on Indonesian rice consumption per capita per year. Rice production data was then converted into national rice production data. Indonesian rice consumption data per capita per year were used to calculate national rice consumption data. National rice production and consumption data were then compared and summarized.

\section{Results and Discussions}

\section{The Estimated Rice Production of Indonesia}

The Ministry of Agriculture (Kementan) has many information systems linked from its main website (pertanian.go.id). Among them are the Strategic Food Information System (Sipastra), Agricultural Statistics Database (BDSP), and Last Five Years Data. These three systems and links publish paddy production data. The difference is, on each page displayed, Sipastra can display detailed data the national, provincial and district levels, while BDSP only displays the total number. For example, when a user chooses to display national paddy production data in these two systems, Sipastra displays paddy production data for all provinces, whereas BDSP does not. BDSP only displays the total amount of paddy 
production in Indonesia. The BDSP states that the data comes from BPS and the Ministry of Agriculture. But when the data is exported into a spreadsheet, the only written source is the Ministry of Agriculture. Another case with that, Sipastra does not include the source of the data.

This study examined the amount of Indonesian rice production in 2014 to 2015 in Sipastra and BDSP. The result is the same. This indicates that it is likely that the Sipastra data also come from BPS. On October 1, 2020, the last data on BDSP was 2017 (Kementan, 2019a), while on Sipastra it could not be known because it was stated that the system was in the maintenance stage and no data could be displayed from all available menus. Meanwhile, in the Last Five Years Data menu, there was data on paddy production in 2014 to 2018 by province (Kementan, 2019b). In the information below those data, it was stated that the data comes from BPS and was a forecast figure from the results of the coordination meeting on July 25-27, 2018.

BPS also only displayed data on paddy production, not rice. Until October 1, 2020, the paddy production data displayed by BPS was only up to 2015, but there were data for 2018 and 2019 (BPS, 2020). Table 2 shows data on paddy production for 2014 to 2019. Data for 2014, 2015, 2018, and 2019 are from BPS, as well as data for 2016 and 2017 from the Last Five Years Data menu on the Ministry of Agriculture website. In this table, it can be seen that rice production from 2014 to 2017 continued to increase but decreased greatly in 2018 and 2019.

Table 2. Production of Paddy in Indonesia, 2014 - 2019 (Ton)

\begin{tabular}{|c|c|c|c|c|c|c|}
\hline Island & 20141) & 20151) & $2016^{2)}$ & 20172) & 20183) & 20193) \\
\hline Sumatera & $16,628,893$ & $18,358,385$ & $20,217,575$ & $21,564,080$ & $11,920,816$ & $10,931,056$ \\
\hline Jawa & $36,663,049$ & $38,970,026$ & $40,893,658$ & $40,055,249$ & $32,557,778$ & $30,328,885$ \\
\hline $\begin{array}{l}\text { Bali \& Nusa } \\
\text { Tenggara }\end{array}$ & $3,800,309$ & $4,219,190$ & $3,865,079$ & $4,250,619$ & $3,027,344$ & $2,793,227$ \\
\hline Kalimantan & $4,847,679$ & $4,830,069$ & $4,839,755$ & $5,098,145$ & $2,949,814$ & $2,921,474$ \\
\hline Sulawesi & $8,508,020$ & $8,615,127$ & $9,095,960$ & $9,704,344$ & $8,331,420$ & $7,227,908$ \\
\hline Maluku Arch. & 174,835 & 193,056 & 181,301 & 188,753 & 165,276 & 136,200 \\
\hline Papua & 223,680 & 211,988 & 261,439 & 287,404 & 248,087 & 265,283 \\
\hline Indonesia & $70,846,465$ & $75,397,841$ & $79,354,767$ & $81,148,594$ & $59,200,534$ & $54,604,033$ \\
\hline
\end{tabular}

This study calculated the estimated rice production from paddy production data in Table 2 using the BPS survey results regarding the percentage of paddy conversion to rice in 2012: $62.47 \%$ (BPS, 2012: 14). However, this conversion value was only used for calculating data before 2018. For 2018 to 2019, the percentage used was $64.02 \%$. This percentage was also an output from BPS (BPS, 2018: 66). The results of the conversion of paddy production data into rice production data are shown in Table 3. 
Table 3. Calculation Result for Estimated Production of Rice in Indonesia, 2014 - 2019 (Ton)

\begin{tabular}{crrrrrr}
\hline Island & $\mathbf{2 0 1 4}$ & $\mathbf{2 0 1 5}$ & $\mathbf{2 0 1 6}$ & $\mathbf{2 0 1 7}$ & $\mathbf{2 0 1 8}$ & $\mathbf{2 0 1 9}$ \\
\hline Sumatera & $10,388,070$ & $11,468,483$ & $12,629,919$ & $13,471,081$ & $7,631,706$ & $6,998,062$ \\
Jawa & $22,903,407$ & $24,344,575$ & $25,546,268$ & $25,022,514$ & $20,843,490$ & $19,416,552$ \\
Bali \& Nusa & $2,374,053$ & $2,635,728$ & $2,414,515$ & $2,655,362$ & $1,938,105$ & $1,788,224$ \\
Tenggara & & & & & & \\
Kalimantan & $3,028,345$ & $3,017,344$ & $3,023,395$ & $3,184,811$ & $1,888,471$ & $1,870,328$ \\
Sulawesi & $5,314,960$ & $5,381,870$ & $5,682,246$ & $6,062,304$ & $5,333,775$ & $4,627,307$ \\
Maluku Arch. & 109,219 & 120,602 & 113,259 & 117,914 & 105,810 & 87,195 \\
Papua & 139,733 & 132,429 & 163,321 & 179,541 & 158,825 & 169,834 \\
Indonesia & $44,257,787$ & $47,001,031$ & $49,572,923$ & $50,693,527$ & $37,900,182$ & $34,957,502$ \\
\hline
\end{tabular}

\section{The Estimated Rice Consumption of Indonesia}

The estimated rice consumption of Indonesia was obtained from the per capita rice consumption per year which was multiplied by the estimated population. This study used rice consumption data from the Ministry of Agriculture's Food Consumption Database shown in Table 4 (Kementan, 2019d). It was written that this data was sourced from BPS. The estimated population per year was obtained from the projected population data. Table 5 shows the projected population data for 2010 to 2020 from BPS (2014).

Table 4. Rice Consumption Data

\begin{tabular}{lc}
\hline Year & Rice Consumption (kg/capita/year) ${ }^{\mathbf{1})}$ \\
\hline 2014 & 84.63 \\
2015 & 84.89 \\
2016 & 86.82 \\
2017 & 81.60 \\
2018 & 80.70 \\
2019 & 78.42 \\
\hline
\end{tabular}

Source: Kementan (2019d)

Table 5. Population Projections Data 2010 to 2020 (in thousand)

\begin{tabular}{cccc}
\hline Island & $\mathbf{2 0 1 0}$ & $\mathbf{2 0 1 5}$ & $\mathbf{2 0 2 0}$ \\
\hline Sumatera & $50,860.30$ & $55,272.90$ & 59337.10 \\
Jawa & $137,033.30$ & $145,143.60$ & 152449.90 \\
Bali \& Nusa Tenggara & $13,129.70$ & $14,108.50$ & 15047.80
\end{tabular}


Volume 6 No. 2, Desember 2020

pISSN: 2460-6162. eISSN: 2527-6476

\begin{tabular}{cccc} 
Kalimantan & $13,850.90$ & $15,343.00$ & 16769.70 \\
Sulawesi & $17,437.10$ & $18,724.00$ & 19934.00 \\
Maluku Arch. & $2,585.20$ & $2,848.80$ & 3110.70 \\
Papua & $3,622.30$ & $4,020.90$ & 4417.20 \\
Indonesia & $238,518.80$ & $255,461.70$ & 271066.40 \\
\hline \multicolumn{3}{c}{ Source: BPS (2014) }
\end{tabular}

The projections data of the population was in the form of 5-year data so that in the period 2010 to 2020 there was only projected numbers of people in 2010, 2015, and 2020. The population increasing percentage from 2010 to 2015 was calculated by the formula:

Population increasing percentage from 2010 to 2015

$$
=\frac{\text { Population projection in } 2015-\text { Population projection in } 2010}{\text { Population projection in } 2010} * 100
$$

The population increasing percentage from 2015 to 2020 were counted by the formula:

\section{Population increasing percentage from 2015 to 2020}

$$
=\frac{\text { Population projection in 2020 }- \text { Population projection in 2015 }}{\text { Population projection in } 2015} * 100
$$

Each of those percentages above then divided by 5 to get the population increasing rate per year in 2011 to 2014 and 2016 to 2019. The results are shown in Table 6.

Table 6. Calculation Result for Population Increasing Percentage in 5 Years and

\begin{tabular}{|c|c|c|c|c|}
\hline \multirow[b]{2}{*}{ Island } & \multicolumn{2}{|c|}{2010 to 2015} & \multicolumn{2}{|c|}{2015 to 2020} \\
\hline & $\begin{array}{l}\text { Population } \\
\text { increasing } \\
\text { percentage } \\
\text { in } 5 \text { years } 1)\end{array}$ & $\begin{array}{r}\text { Population } \\
\text { increasing } \\
\text { percentage } \\
\text { per year }{ }^{2)}\end{array}$ & $\begin{array}{r}\text { Population } \\
\text { increasing } \\
\text { percentage } \\
\text { in } 5 \text { years }\end{array}$ & $\begin{array}{r}\text { Population } \\
\text { increasing } \\
\text { percentage per } \\
\text { year }{ }^{4}\end{array}$ \\
\hline Sumatera & 8.68 & 1.74 & 7.35 & 1.47 \\
\hline Jawa & 5.92 & 1.18 & 5.03 & 1.01 \\
\hline $\begin{array}{l}\text { Bali \& Nusa } \\
\text { Tenggara }\end{array}$ & 7.45 & 1.49 & 6.66 & 1.33 \\
\hline Kalimantan & 10.77 & 2.15 & 9.30 & 1.86 \\
\hline Sulawesi & 7.38 & 1.48 & 6.46 & 1.29 \\
\hline Maluku Arch. & 10.20 & 2.04 & 9.19 & 1.84 \\
\hline Papua & 11.00 & 2.20 & 9.86 & 1.97 \\
\hline Indonesia & 7.10 & 1.42 & 6.11 & 1.22 \\
\hline
\end{tabular}
Per Year 
From the population increasing percentage per year in Table 6, this study obtained the estimated population of Indonesia in 2014 and 2016 to 2019 using:

Estimated Population in year_x

$$
\begin{aligned}
& =((\text { year_ } x-\text { year } 0) \\
& * \frac{\text { Population increasing percentage per year from year0 to year5 }}{100} \\
& * \text { Population projection in year } 0)+ \text { Population projection in year0 }
\end{aligned}
$$

where year_x: the year for which the estimated population size is being sought. year0 or year5: the year for which the population projection was known from BPS (2010/2015).

The calculation result for the estimated population is shown in Table 7.

Table 7. Calculation Result for the Estimated Population in 2014 and 2016 to 2019 (in Thousand)

\begin{tabular}{cccccc}
\hline Island & $\mathbf{2 0 1 4}$ & $\mathbf{2 0 1 6}$ & $\mathbf{2 0 1 7}$ & $\mathbf{2 0 1 8}$ & $\mathbf{2 0 1 9}$ \\
\hline Sumatera & $54,390.38$ & $56,085.74$ & $56,898.58$ & $57,711.42$ & $58,524.26$ \\
Jawa & $143,521.54$ & $146,604.86$ & $148,066.12$ & $149,527.38$ & $150,988.64$ \\
Bali \& Nusa & $13,912.74$ & $14,296.36$ & $14,484.22$ & $14,672.08$ & $14,859.94$ \\
Tenggara & & & & & \\
Kalimantan & $15,044.58$ & $15,628.34$ & $15,913.68$ & $16,199.02$ & $16,484.36$ \\
Sulawesi & $18,466.62$ & $18,966.00$ & $19,208.00$ & $19,450.00$ & $19,692.00$ \\
Maluku Arch. & $2,796.08$ & $2,901.18$ & $2,953.56$ & $3,005.94$ & $3,058.32$ \\
Papua & $3,941.18$ & $4,100.16$ & $4,179.42$ & $4,258.68$ & $4,337.94$ \\
Indonesia & $252,073.12$ & $258,582.64$ & $261,703.58$ & $264,824.52$ & $267,945.46$ \\
\hline
\end{tabular}

From the data on rice consumption per capita per year in Table 4, Population Projections for 2010 - 2020 in Table 5, and the estimated population per island per year in Table 7, an estimation of rice consumption per island in Indonesia from 2014 to 2019 was obtained (shown in Table 8).

Table 8. Calculation Result for the Estimated Consumption of Rice in Indonesia, 2014 - 2019 (Ton)

\begin{tabular}{crrrrrr}
\hline Island & \multicolumn{1}{c}{$\mathbf{2 0 1 4}$} & \multicolumn{1}{c}{$\mathbf{2 0 1 5}$} & \multicolumn{1}{c}{$\mathbf{2 0 1 6}$} & \multicolumn{1}{c}{$\mathbf{2 0 1 7}$} & \multicolumn{1}{c}{$\mathbf{2 0 1 8}$} & \multicolumn{1}{c}{$\mathbf{2 0 1 9}$} \\
\hline Sumatera & $4,603,057.86$ & $4,692,116.48$ & $4,869,363.95$ & $4,642,924.13$ & $4,657,311.59$ & $4,589,472.47$ \\
Jawa & $12,146,227.93$ & $12,321,240.20$ & $12,728,233.95$ & $12,082,195.39$ & $12,066,859.57$ & $11,840,529.15$ \\
Bali \& & $1,177,435.19$ & $1,197,670.57$ & $1,241,209.98$ & $1,181,912.35$ & $1,184,036.86$ & $1,165,316.49$
\end{tabular}


Volume 6 No. 2, Desember 2020

pISSN: 2460-6162. eISSN: 2527-6476

Nusa

Tenggara

Kalimanta

$1,273,222.81$

$1,302,467.27$

$1,356,852.48$

$1,298,556.29$

$1,307,260.91$

$1,292,703$

$\mathrm{n}$

Sulawesi

$1,562,830.05$

$1,589,480.36$

$1,646,628.12$

$1,567,372.80$

$1,569,615.00$

$1,544,246.64$

Maluku

$236,632.25$

$241,834.63$

$251,880.45$

$241,010.50$

$242,579.36$

$239,833.45$

Arch.

Papua

$333,542.06$

$341,334.20$

$355,975.89$

$341,040.67$

$343,675.48$

$340,181.25$

Indonesia

\section{Comparison of Rice Production and Consumption Estimation in Indonesia}

After obtaining the estimated rice production and consumption data in 2014 to 2019 shown in Table 3 and 8 respectively, this study compared both data (shown in Table 9 and 10).

Table 9. Comparison of Estimated Production and Consumption of Rice in Indonesia, 2014-2016 (Ton)

\begin{tabular}{|c|c|c|c|c|c|c|}
\hline \multirow[t]{2}{*}{ Island } & \multicolumn{2}{|c|}{2014} & \multicolumn{2}{|c|}{2015} & \multicolumn{2}{|c|}{2016} \\
\hline & $\begin{array}{r}\text { Estimated rice } \\
\text { production }\end{array}$ & $\begin{array}{r}\text { Estimated rice } \\
\text { consumption }\end{array}$ & $\begin{array}{r}\text { Estimated rice } \\
\text { production }\end{array}$ & $\begin{array}{r}\text { Estimated rice } \\
\text { consumption }\end{array}$ & $\begin{array}{r}\text { Estimated rice } \\
\text { production }\end{array}$ & $\begin{array}{l}\text { Estimated rice } \\
\text { consumption }\end{array}$ \\
\hline Sumatera & $10,388,069.46$ & $4,603,057.86$ & $11,468,483.11$ & $4,692,116.48$ & $12,629,919.10$ & $4,869,363.95$ \\
\hline Jawa & $22,903,406.71$ & $12,146,227.93$ & $24,344,575.24$ & $12,321,240.20$ & $25,546,268.15$ & $12,728,233.95$ \\
\hline $\begin{array}{c}\text { Bali \& Nusa } \\
\text { Tenggara }\end{array}$ & $2,374,053.03$ & $1,177,435.19$ & $2,635,727.99$ & $1,197,670.57$ & $2,414,514.85$ & $1,241,209.98$ \\
\hline Kalimantan & $2,956,117.26$ & $1,273,222.81$ & $2.947,313.98$ & $1,302,467.27$ & $3,023,394.95$ & $1,356,852.48$ \\
\hline Sulawesi & $5,314,960.09$ & $1,562,830.05$ & $5,381,869.84$ & $1,589,480.36$ & $5,682,246.21$ & $1,646,628.12$ \\
\hline $\begin{array}{l}\text { Maluku } \\
\text { Arch. }\end{array}$ & $109,219.42$ & $236,632.25$ & $120,602.08$ & $241,834.63$ & $113,258.73$ & $251,880.45$ \\
\hline Papua & $139,732.90$ & $333,542.06$ & $132,428.90$ & $341,334.20$ & $162,848.67$ & $355,975.89$ \\
\hline Indonesia & $44,185,558.87$ & $21,332,948.15$ & $47,031,001.15$ & $21,686,143.71$ & $49,572,450.67$ & $22,450,144.80$ \\
\hline
\end{tabular}

Table 10. Comparison of Estimated Production and Consumption of Rice in Indonesia, 2017 - 2019 (Ton)

\begin{tabular}{|c|c|c|c|c|c|c|}
\hline \multirow[t]{2}{*}{ Island } & \multicolumn{2}{|c|}{2017} & \multicolumn{2}{|c|}{2018} & \multicolumn{2}{|c|}{2019} \\
\hline & $\begin{array}{r}\text { Estimated rice } \\
\text { production }\end{array}$ & $\begin{array}{l}\text { Estimated rice } \\
\text { consumption }\end{array}$ & $\begin{array}{r}\text { Estimated rice } \\
\text { production }\end{array}$ & $\begin{array}{l}\text { Estimated rice } \\
\text { consumption }\end{array}$ & $\begin{array}{r}\text { Estimated rice } \\
\text { production }\end{array}$ & $\begin{array}{l}\text { Estimated rice } \\
\text { consumption }\end{array}$ \\
\hline Sumatera & $13,471,080.78$ & $4,642,924.13$ & $7,631,706$ & $4,657,311.59$ & $6,998,062$ & $4,589,472.47$ \\
\hline Jawa & $25,022,514.05$ & $12,082,195.39$ & $20,843,490$ & $12,066,859.57$ & $19,416,552$ & $11,840,529.15$ \\
\hline $\begin{array}{c}\text { Bali \& Nusa } \\
\text { Tenggara }\end{array}$ & $2,655,361.69$ & $1,181,912.35$ & $1,938,105$ & $1,184,036.86$ & $1,788,224$ & $1,165,316.49$ \\
\hline Kalimantan & $3,184,811.18$ & $1,298,556.29$ & $1,888,471$ & $1,307,260.91$ & $1,870,328$ & $1,292,703$ \\
\hline Sulawesi & $6,062,303.70$ & $1,567,372.80$ & $5,333,775$ & $1,569,615.00$ & $4,627,307$ & $1,544,246.64$ \\
\hline
\end{tabular}


JAKPP (Jurnal Analisis Kebijakan dan Pelayanan Publik)

6(2), 101-112: A Comparative Study of Indonesian Estimated Rice Production and Consumption

\begin{tabular}{crrrrrr}
$\begin{array}{c}\text { Maluku } \\
\text { Arch. }\end{array}$ & $117,914.00$ & $241,010.50$ & 105,810 & $242,579.36$ & 87,195 & $239,833.45$ \\
Papua & $179,541.28$ & $341,040.67$ & 158,825 & $343,675.48$ & 169,834 & $340,181.25$ \\
Indonesia & $50,693,526.67$ & $21,355,012.13$ & $37,900,182$ & $21,371,338.76$ & $34,957,502$ & $21,012,282.97$ \\
\hline
\end{tabular}

\section{Conclusion}

The results of calculations in Tables 9 and 10 shows that of the seven islands, only two islands which their rice consumption estimation was more than the production, that is the Maluku Islands and Papua Island. However, the total rice consumption estimation in Indonesia was always lower than the production. The rice surplus in the closest island, namely Sulawesi, is supposed to cover the shortage in Maluku and Papua. If the estimated consumption of rice in these three islands was totaled, the amount was always smaller than the estimated rice production on those islands. This condition was because the huge production of paddy in Sulawesi. Table 10 shows that the total estimated consumption of rice in 2019 was only $60 \%$ of its estimated production.

Abidin (2015) stated that rice tends to experience an increase in surplus during the harvest period (February to April). Meanwhile, the dry season or planting season (October to January) experienced a deficit. This needs to be confirmed in the next research by looking at the monthly data on rice production, estimating rice production, and making comparisons as has been done above. BPS explained that rice production data comes from the yield of harvested area and productivity (BPS, n.d.). The harvested area was collected through an Agricultural Survey conducted by officers from the Department of Agriculture. This information is collected monthly from each sub-district in Indonesia. Productivity data were collected from the survey conducted by officers from the Agriculture Office and the District Statistics Coordinator. The timing of the survey is adjusted to the time of harvest. If there is an increase in the surplus from February to April, and there is a shortage of stock in October to January, further research can investigate the possibility of storing a surplus of rice during the harvest period until January, so that it can meet people's consumption needs.

\section{Acknowledgment}

This article was author's research at the Center for Research and Community Service at the College of Multimedia "MMTC" Yogyakarta in 2019.

\section{Daftar Pustaka}

Abidin, M. Z. (2015). Dampak Kebijakan Impor Beras dan Ketahanan Pangan dalam Perspektif Kesejahteraan Sosial. Sosio Informa, 1(3), hlm. 213-230.

Badan Pusat Statistik. (n.d.). Metodologi. Retrieved from October 16, 2020 from https://www.bps.go.id/subject/53/tanaman-pangan.html\#subjekViewTab2. 
Badan Pusat Statistik. (November 30, 2012). Konversi Gabah Kering Giling (GKG) ke Beras Tahun 2012. Retrieved November 5, 2019 from https:/ / www.bps.go.id/publication/2012/11/30/8a91cd0832f473fd54d9cdd9 / konversi-gabah-kering-giling--gkg--ke-beras-tahun-2012.html.

Badan Pusat Statistik. (February 18, 2014). Proyeksi Penduduk menurut Provinsi, 2010-2035 (Ribuan). Retrieved October 1, 2020 from https:/ / www.bps.go.id/statictable/2014/02/18/1274/proyeksi-pendudukmenurut-provinsi-2010---2035.html.

Badan Pusat Statistik. (July 1, 2016). Produksi Padi Menurut Provinsi (ton), 19932015. Retrieved October $1, \quad 2020$ from https:// www.bps.go.id/dynamictable/2015/09/09/865/produksi-padimenurut-provinsi-ton-1993-2015.html.

Badan Pusat Statistik. (December 21, 2018). SKGB 2018 - Konversi Gabah ke Beras. Retrieved October $\quad 1, \quad 2020 \quad$ from https:/ / www.bps.go.id/publication/2018/12/21/029eabe94ce2660ca5ade63 a/konversi-gabah-ke-beras--skgb--tahun-2018.html.

Badan Pusat Statistik. (October 29, 2019). Impor Beras Menurut Negara Asal Utama, 2000-2018. Retrieved December 6, 2019 from https://www.bps.go.id/statictable/2014/09/08/1043/impor-beras-menurutnegara-asal-utama-2000-2018.html.

Badan Pusat Statistik. (February 13, 2020). Luas Panen, Produksi, dan Produktivitas Padi Menurut Provinsi 2018-2019. Retrieved October 1, 2020 from https:/ / www.bps.go.id/indicator/53/1498/1/luas-panen-produksi-danproduktivitas-padi-menurut-provinsi.html.

Erdianto, K. \& Belarminus, R. (February 18, 2019). Alasan Jokowi Tetap Impor meski Stok Cadangan Beras Surplus. Retrieved August 11, 2019 from https://nasional.kompas.com/read/2019/02/18/00072271/alasan-jokowitetap-impor-meski-stok-cadangan-beras-surplus.

Fitri, S. \& Rachman, T. (November 16, 2015). Beras Impor Bukti Kegagalan Bulog Serap Beras Petani. Retrieved August 8, 2019 from http://www.republika. co.id/berita/ekonomi/makro/15/11/16/nxwvjk219-beras-impor-buktikegagalan-bulog-serap-beras-petani.

Herdahita, R. \& Aini, N. (November 13, 2015). Kabar Impor Beras Bisa Picu Praktik Kartel Dagang. Retrieved August 8, 2019 from http:/ / www.republika.co.id/berita/ekonomi/makro/15/11/13/nxr4zi382kabar-impor-beras-bisa-picu-praktik-kartel-dagang.

Ian. (November 18, 2015). Akhir Cerita Impor Beras: Kepri Tak Dapat Kuota, hanya Tetesan. Retrieved August 8, 2019 from http://batampos.co.id/18-11-2015/ akhir-cerita-impor-beras-kepri-tak-dapat-kuota-hanya-tetesan/.

Kementerian Pertanian RI. (2019a). Basis Data Statistik Pertanian. Retrieved October 29, 2019 from http:/ / aplikasi2.pertanian.go.id/bdsp/

Kementerian Pertanian RI. (2019b). Data Lima Tahun Terakhir. Retrieved October 29, 2019 from https:/ / pertanian.go.id/home/?show=page\&act=view\&id=61 Kementerian Pertanian RI. (2019c). Tabel 2.1.3. Produksi Padi1) Menurut Provinsi, 2014 - 2018. Retrieved October 29, 2019 from 
https://www.pertanian.go.id/Data5tahun/TPATAP-2017(pdf)/20ProdPadi.pdf.

Kementerian Pertanian RI. (2019d). Basis Data Konsumsi Pangan. Retrieved November 1, 2019 from aplikasi2.pertanian.go.id/konsumsi/home_awal.php.

Kementerian Pertanian RI. (n.d.c). Indonesia Tingkatkan Produksi Padi dan Jagung. Retrieved January $\quad 4, \quad 2020 \quad$ from https:// www.pertanian.go.id/home/?show=news\&act=view\&id=3558.

Maulida, A. (August 29, 2018). Kemdag: Realisasi Impor Beras Bulog Sudah 86. Retrieved August 8, 2019 from https://industri.kontan.co.id/news/kemdagrealisasi-impor-beras-bulog-sudah-86.

Nainggolan, J. (January 13, 2018). Isu Impor Buat Petani Resah, Harga Gabah Juga Ikut Anjlok. Retrieved August 8, 2019 from https:// ekbis.rmol.co/read/2018/01/13/322130/Isu-Impor-Buat-PetaniResah,-Harga-Gabah-Juga-Ikut-Anjlok.

Pitoko, R. A. (May 22, 2018). Polemik Impor Beras dan Ketidakakuratan Data Produksi Beras Nasional. Retrieved August 8, 2019 from https://ekonomi.kompas.com/read/2018/05/22/083900026/polemik-imporberas-dan-ketidakakuratan-data-produksi-beras-nasional.

Rungkat, D. M., Rumagit, G. A. J., Ngangi, C. R., \& Ruauw, E. (2014). Analisis Faktor-Faktor yang Mempengaruhi Impor Beras di Sulawesi Utara. Cocos, 4 (2), 28-41.

Santosa, I. G. N., Adnyana, G. M., \& Dinata, I. K. K. (2011). Dampak Alih Fungsi Lahan Sawah terhadap Ketahanan Pangan Beras. Prosiding Seminar Nasional Budidaya Pertanian.

Thomas, V. F. (March 12, 2020). Pemerintah Berencana Buka Keran Impor Beras Lagi di 2020. Retrieved October 14, 2020 from https://tirto.id/pemerintah-berencanabuka-keran-impor-beras-lagi-di-2020-eEvT

Yuliawati \& Alika, R. (December 6, 2019). Bulog Buang Beras 20 Ribu Ton, Buah dari Kebijakan Salah Hitung Impor? Retrieved December 11, 2019 from https:// katadata.co.id/berita/2019/12/06/bulog-buang-beras-20-ribu-tonbuah-dari-kebijakan-salah-hitung-impor.

World Bank. (2019a). Land area (sq. km). Retrieved January 24, 2020 from http://data.worldbank.org/indicator/AG.LND.TOTL.K2/countries.

World Bank. (2019b). Agricultural land (sq. km). Retrieved January 24, 2020 from https:// data.worldbank.org/indicator/ AG.LND.AGRI.K2.

World Bank. (2019c). Agricultural land (\% of land area). Retrieved January 24, 2020 from https:/ / data.worldbank.org/indicator/AG.LND.AGRI.ZS. 